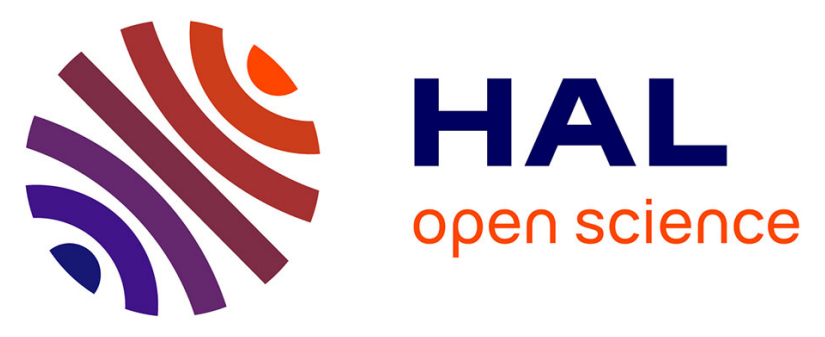

\title{
Inherited Thrombotic Thrombocytopenic Purpura Revealed by Recurrent Strokes in a Male Adult: Case Report and Literature Review
}

Diane Beauvais, Laura Venditti, Olivier Chassin, Bérangère Joly, Alain Ameri, Pierre Boisseau, Olivier Lambotte, Paul Coppo, Agnès Veyradier, Christian

Denier

\section{To cite this version:}

Diane Beauvais, Laura Venditti, Olivier Chassin, Bérangère Joly, Alain Ameri, et al.. Inherited Thrombotic Thrombocytopenic Purpura Revealed by Recurrent Strokes in a Male Adult: Case Report and Literature Review. Journal of Stroke and Cerebrovascular Diseases, 2019, 28, pp.1537 - 1539. 10.1016/j.jstrokecerebrovasdis.2019.03.011 . hal-03484712

\author{
HAL Id: hal-03484712 \\ https://hal.science/hal-03484712
}

Submitted on 20 Dec 2021

HAL is a multi-disciplinary open access archive for the deposit and dissemination of scientific research documents, whether they are published or not. The documents may come from teaching and research institutions in France or abroad, or from public or private research centers.
L'archive ouverte pluridisciplinaire HAL, est destinée au dépôt et à la diffusion de documents scientifiques de niveau recherche, publiés ou non, émanant des établissements d'enseignement et de recherche français ou étrangers, des laboratoires publics ou privés.

\section{(ㅇ)(1) $\$$}

Distributed under a Creative Commons Attribution - NonCommerciall 4.0 International 
Inherited thrombotic thrombocytopenic purpura revealed by recurrent strokes in a male adult: case report and literature review.

Authors: Diane Beauvais ${ }^{1 *}$, Laura Venditti ${ }^{1 *}$, Olivier Chassin ${ }^{1}$, Bérangère Joly ${ }^{2}$, Alain Ameri ${ }^{3}$, Pierre Boisseau ${ }^{2}$, Olivier Lambotte ${ }^{4}$, Paul Coppo ${ }^{5}$, Agnès Veyradier ${ }^{2}$ and Christian Denier $^{1}$

\section{Affiliations:}

${ }^{1}$ Department of Neurology, Bicêtre Hospital, AP-HP, University Paris Sud Saclay, ${ }^{2}$ Haematology biology department, Lariboisière Hospital, AP-HP and EA3518, University Paris Diderot, ${ }^{3}$ Neurology, Meaux Hospital, ${ }^{4}$ Internal medicine, Bicêtre Hospital, AP-HP, University Paris Sud Saclay, and ${ }^{5}$ Haematology department, Saint Antoine Hospital, AP-HP, University Pierre et Marie Curie, Paris Diderot.

* Both authors contributed equally to this work.

Correspondence to Dr Laura Venditti, Department of Neurology, Hôpital de Bicêtre, 78 rue du Général Leclerc, 94275 Le Kremlin-Bicêtre, France. E-mail : laura.vendittigzl@gmail.com

Title: 127 characters; Short title: 44 characters; Abstract: 180 words; Text word count: 372;

References: 8; Table: 1.

Short title: Upshaw-Schulman syndrome revealed by stroke

Disclosure: none. 


\begin{abstract}
Thrombotic thrombocytopenic purpura (TTP) is a thrombotic microangiopathy related to a severe deficiency of ADAMTS13 (a disintegrin and metalloprotease with thrombospondin type 1 repeats, member 13). In this article, we describe the first case of a young male adult suffering from a hereditary TTP revealed by recurrent strokes, relapsing despite antiplatelet and anticoagulant therapy. Because of the persistent moderate thrombocytopenia, plasmatic ADAMTS13 activity was investigated and was found lower than $5 \%$ in the absence of anti-ADAMTS13 IgG. Direct sequencing of ADAMTS13 gene led to the diagnosis of Upschaw-Schulman syndrome (USS). Inherited TTP or USS is a rare autosomal recessive inherited disease leading to a severe deficiency of ADAMTS13 mostly beginning in childhood or in young female adult during pregnancy. Our patient was treated with fresh frozen plasma every two weeks. One year after diagnosis, he was free of neurological symptoms. Around 12 cases of inherited TTP diagnosed in adults (outside pregnancy) are described in literature. Only 4 of them exhibited a stroke. This case is the first late onset genetic TTP revealed by recurrent strokes, moderate thrombocytopenia without anemia.
\end{abstract}

Key words: Stroke ; Thrombocytopenia ADAMTS13 ; Thrombotic thrombocytopenic purpura ; Neurogenetic 


\section{Observation}

A 33-year-old Caucasian without any family history presented to the emergency department because of an acute left-side weakness that spontaneously recovered after thirty minutes. Cerebral magnetic resonance imaging (MRI) revealed an acute right parietal ischemic stroke. Neck and intra-cranial arteries explored were normal. 24-hour electrocardiogram monitoring excluded arrhythmia. Body tomodensitometry revealed both renal and spleen infarcts. Transesophageal echography and hematologic parameters (bone marrow smear and biopsy, screening for mutations of myeloproliferative syndroms) were normal. The patient was treated with aspirin.

Recurrence occurred one month later with right-side weakness revealing a new cerebral infarct in the superficial left parietal lobe on MRI. Biological examinations were still negative except a moderate thrombocytopenia $\left(100 \times 10^{9} / L\right)$ without signs of hemolysis. Patient was administered anticoagulation therapy (apixaban).

A third episode occurred two months later. Lumbar puncture and X-rays cerebral arteriography were normal. Because of the thrombocytopenia, ADAMTS13 (a disintegrin and metalloprotease with thrombospondin type 1 repeats, member 13) activity (measured using the FRETS-VWF73 assay as previously described)(1) was investigated and was found lower than $5 \%$, in the absence of anti-ADAMTS13 IgG. Direct sequencing of ADAMTS13 gene showed two heterozygous mutations in exon 24 consisting in one missense mutation p.Arg1060Trp and one truncating mutation p.Trp1067Serfs*47. Also, several single nucleotide polymorphisms (SNPs) were identified either at the homozygous state (p.Arg7Trp) or at the heterozygous state (p.GIn448Glu, p.Pro618Ala and p.Ala1033Thr). This result led to the diagnosis of congenital TTP. The patient was treated with fresh frozen plasma. One year after diagnosis, the patient did not relapse. 


\section{Discussion}

TTP is a thrombotic microangiopathy related to a severe deficiency of ADAMTS13 $(2,3)$ leading to a spontaneous formation of platelet thrombi responsible for a mechanical hemolytic anemia, a thrombocytopenia and a multivisceral ischemia with often brain involvement (stroke, seizure or confusion). Indeed, ADAMTS13 plays a key role in the control of platelet adhesion and aggregation by cleaving the von Willebrand factor (VWF) multimers. In almost $90 \%$ of cases, TTP is acquired(1). In the other cases, TTP is inherited via bi-allelic autosomal recessive mutations of ADAMTS13 gene (Upschaw-Schulman syndrome)(4). Clinical presentation of USS is variable, mostly beginning in childhood or in young female adult during pregnancy. Around 12 cases diagnosed in adults (outside pregnancy) are described in literature. Only 4 of them (Table 1)(5-8) exhibited a stroke. All these cases had severe thrombocytopenia and microangiopathic haemolytic anemia.

\section{Conclusion}

This case is the first late onset genetic TTP revealed by recurrent strokes, moderate thrombocytopenia without anemia. A stroke with thrombocytopenia, even moderate, needs to discuss a TTP and ADAMTS13 activity should be tested. The absence of anemia or schistocytes should not call into question the diagnosis of TTP. In perspective, impact of acquired or genetically inherited low ADAMTS13 activity to promote strokes will remains to be explored in future large studies (9). 


\section{References}

1. Mariotte E, Azoulay E, Galicier L, Rondeau E, Zouiti F, Boisseau P, et al. Epidemiology and pathophysiology of adulthood-onset thrombotic microangiopathy with severe ADAMTS13 deficiency (thrombotic thrombocytopenic purpura): a cross-sectional analysis of the French national registry for thrombotic microangiopathy. Lancet Haematol. mai 2016;3(5):e237-245.

2. Levy GG, Nichols WC, Lian EC, Foroud T, McClintick JN, McGee BM, et al. Mutations in a member of the ADAMTS gene family cause thrombotic thrombocytopenic purpura. Nature. 4 oct 2001;413(6855):488?94.

3. Pérez-Rodríguez A, Lourés E, Rodríguez-Trillo Á, Costa-Pinto J, García-Rivero A, BatlleLópez A, et al. Inherited ADAMTS13 deficiency (Upshaw-Schulman syndrome): a short review. Thromb Res. déc 2014;134(6):1171? 5.

4. Joly BS, Coppo P, Veyradier A. Thrombotic thrombocytopenic purpura. Blood. 25 mai 2017;129(21):2836?46.

5. Meyer SC, Jeddi R, Meddeb B, Gouider E, Lämmle B, Kremer Hovinga JA. A first case of congenital TTP on the African continent due to a new homozygous mutation in the catalytic domain of ADAMTS13. Ann Hematol. août 2008;87(8):663国6.

6. Antoine G, Zimmermann K, Plaimauer B, Grillowitzer M, Studt J-D, Lammle B, et al. ADAMTS13 gene defects in two brothers with constitutional thrombotic thrombocytopenic purpura and normalization of von Willebrand factor-cleaving protease activity by recombinant human ADAMTS13. British Journal of Haematology. mars 2003;120(5):821?4.

7. Fattah H, Kumar D, George JN, Massey HD, King AL, Friedman KD, et al. Successful kidney transplantation in a patient with congenital thrombotic thrombocytopenic purpura (Upshaw-Schulman syndrome). Transfusion. déc 2017;57(12):3058?62.

8. Hyla-Klekot L, Kucharska G, Słonka K. [Variety of thrombotic thrombocytopenic purpura clinical course in Polish family members with ADAMTS 13 gene mutation]. Pol Merkur Lekarski. mars 2013;34(201):161?4.

9. Lambers M, Goldenberg NA, Kenet G, Kirkham FJ, Manner D, Bernard T, et al. Role of reduced ADAMTS13 in arterial ischemic stroke: a pediatric cohort study. Ann Neurol. janv 2013;73(1):58?64. 


\begin{tabular}{|c|c|c|c|c|c|c|c|c|c|c|}
\hline Reference & $\begin{array}{l}\text { Sex, age at } \\
\text { diagnosis, } \\
\text { origin }\end{array}$ & $\begin{array}{l}\text { Medical history } \\
\text { before diagnosis }\end{array}$ & $\begin{array}{l}\text { Symptoms at } \\
\text { diagnosis }\end{array}$ & Stroke & $\begin{array}{l}\text { Triggering } \\
\text { factor }\end{array}$ & Treatment & $\begin{array}{l}\text { Biological } \\
\text { results }\end{array}$ & $\begin{array}{l}\text { ADAMTS13 } \\
\text { activity }\end{array}$ & $\begin{array}{l}\text { Mutations of } \\
\text { ADAMTS13 gene }\end{array}$ & Evolution \\
\hline Meyer et al ${ }^{5}$ & $\begin{array}{l}\text { Male, 20, } \\
\text { Tunisian }\end{array}$ & $\begin{array}{l}17 \text { years old: } \\
\text { petechial bleeding } \\
\text { and epistaxis with } \\
\text { thrombocytopenia } \\
\text { and anemia } \\
\text { without signs of } \\
\text { hemolysis. } \\
\text { Diagnosis of } \\
\text { idiopathic } \\
\text { thrombocytopenic } \\
\text { purpura, treated by } \\
\text { corticosteroids }\end{array}$ & $\begin{array}{l}\text { Ischemic stroke } \\
\text { with generalized } \\
\text { seizures }\end{array}$ & $\begin{array}{l}\text { Lacunar } \\
\text { strokes }\end{array}$ & 0 & $\begin{array}{l}\text { Polyvalent } \\
\text { intravenous } \\
\text { immune- } \\
\text { globulins } \\
\text { and } \\
\text { sessions of } \\
\text { plasmapher } \\
\text { esis. } \\
\text { FFP after } \\
\text { diagnosis of } \\
\text { inherited } \\
\text { TTP. }\end{array}$ & $\begin{array}{l}\text { Platelets: } \\
\text { 13x109/L } \\
\text { Hemolytic } \\
\text { anemia (Hb } 77 \\
\text { g/L; total } \\
\text { bilirubin } 107 \\
\mu \text { mol/L; and } \\
\text { LDH 1,095 IU, } \\
\text { normal range } \\
\text { 91-180 IU). } \\
\text { Schistocytes: } \\
\text { only detected } \\
\text { at the 3rd crisis. }\end{array}$ & $\begin{array}{l}<5 \% \\
\text { (diagnosis at } \\
21 \text { years old, } \\
\text { on third } \\
\text { hemolytic } \\
\text { crisis) }\end{array}$ & $\begin{array}{l}\text { Homozygous for a } \\
\text { missense mutation: } \\
\text { p.Ser119Phe in the } \\
\text { metalloprotease } \\
\text { domain of } \\
\text { ADAMTS13 }\end{array}$ & $\begin{array}{l}\text { Follow-up of } 2.5 \text { years: } \\
\text { sustained remission (platelet } \\
\text { count }>100 \times 10^{9} / \mathrm{L} \text { ) with } \\
\text { persistent mild renal } \\
\text { insufficiency (serum creatinine } \\
150 \mu \mathrm{mol} / \mathrm{I} \text { ), however, without } \\
\text { neurological sequelae. }\end{array}$ \\
\hline Antoine et $\mathrm{al}^{6}$ & $\begin{array}{l}\text { Male, 21, } \\
\text { "white" } \\
\text { "patient A1 } \\
\text { born in 1964" }\end{array}$ & 0 & $\begin{array}{l}\text { Ictere, renal } \\
\text { failure, } \\
\text { somnolence, } \\
\text { abdominal pain. } \\
\text { Relapses: renal } \\
\text { failure, strokes } \\
\text { and seizures }\end{array}$ & $\begin{array}{l}25 \text { years old: } \\
\text { ischemic } \\
\text { stroke in the } \\
\text { right medium } \\
\text { cerebral } \\
\text { artery } \\
\text { territory }\end{array}$ & $\begin{array}{l}\text { First relapse } \\
\text { following } \\
\text { febrile } \\
\text { illness and } \\
\text { acetylsalicyl } \\
\text { ic acid } \\
\text { intake. } \\
\text { Other } \\
\text { episodes } \\
\text { preceded } \\
\text { by infection } \\
\text { or surgery. }\end{array}$ & $\begin{array}{l}\text { Hemodialysi } \\
\text { s, FFP. After } \\
\text { the } 10^{\text {th }} \\
\text { bout of TTP, } \\
\text { prophylacti } \\
\text { c } \\
\text { plasmapher } \\
\text { esis } \\
\text { sessions } \\
\text { every } 4 \\
\text { months } \\
\text { were } \\
\text { instituted. }\end{array}$ & $\begin{array}{l}\text { Platelets: } 15 \times 10^{9} \\
/ \mathrm{L} . \mathrm{Hb}: 108 \mathrm{~g} / \mathrm{L} \\
\text { at diagnosis and } \\
\text { chronic low- } \\
\text { grade } \\
\text { microangiopath } \\
\text { ic hemolysis on } \\
\text { follow-up. } \\
\text { Schistocytes: } \\
\text { present at } \\
\text { every bout }\end{array}$ & $<3 \%$ & $\begin{array}{l}\text { Compound } \\
\text { heterozygote with } 2 \\
\text { mutations:, } \\
\text { p.Arg732Val (exon } \\
\text { 18) and p.Arg1336Trp } \\
\text { (exon 28) }\end{array}$ & $\begin{array}{l}\text { More than } 10 \text { years' follow-up, } \\
\text { with } 10 \text { bouts including one } \\
\text { occurring during the } \\
\text { prophylactic treatment with } \\
\text { FFP every } 4 \text { months }\end{array}$ \\
\hline
\end{tabular}




\begin{tabular}{|c|c|c|c|c|c|c|c|c|c|c|}
\hline Fattah et al ${ }^{7}$ & $\begin{array}{l}\text { Female, 48, } \\
\text { Caucasian }\end{array}$ & $\begin{array}{l}32 \text { years old: stroke } \\
\text { involving multiple } \\
\text { territories. } \\
\text { Thrombocytopenia, } \\
\text { hemolytic anemia. } \\
\text { Treated with } 3 \text { days } \\
\text { of plasma exchange } \\
\text { for suspected TTP. } \\
\text { She developed } \\
\text { progressive chronic } \\
\text { kidney disease that } \\
\text { was presumed } \\
\text { secondary to } \\
\text { hypertension. }\end{array}$ & $\begin{array}{l}\text { Kidney } \\
\text { transplantation } \\
\text { for renal end- } \\
\text { stage disease }\end{array}$ & $\begin{array}{l}32 \text { years old: } \\
\text { strokes in } \\
\text { multiple } \\
\text { vascular } \\
\text { territories }\end{array}$ & $\begin{array}{l}\text { Kidney } \\
\text { transplantat } \\
\text { ion }\end{array}$ & FFP & $\begin{array}{l}\text { Her hemoglobin } \\
(\mathrm{Hb}) \\
\text { concentration } \\
\text { decreased from } \\
10 \text { to } 8 \mathrm{~g} / \mathrm{dL}\end{array}$ & $<5 \%$ & $\begin{array}{l}\text { Compound } \\
\text { heterozygote: } \\
\text { p.Arg916Cys (exon } \\
22 \text { ) and at Exon } 29 \\
\text { (c4143insA) results in } \\
\text { a frame shift of the } \\
\text { protein sequence } \\
\text { starting with glutamic } \\
\text { acid at Codon } 1382 \\
\text { (p.Glu1382fs) }\end{array}$ & No relapse \\
\hline $\begin{array}{l}\text { Hyla-Klekot } \\
\text { et al }{ }^{8}\end{array}$ & $\begin{array}{l}\text { Male, 52, } \\
\text { Polish }\end{array}$ & $\begin{array}{l}\text { He experienced a } \\
\text { few episodes of } \\
\text { ischemic stroke } \\
\text { with ongoing } \\
\text { neurological } \\
\text { deficiency and } \\
\text { developed chronic } \\
\text { kidney disease. }\end{array}$ & NA & $\begin{array}{l}\text { Ischemic } \\
\text { strokes } \\
\text { without more } \\
\text { precision }\end{array}$ & NA & NA & NA & NA & $\begin{array}{l}\text { Compound } \\
\text { heterozygote: } \\
\text { missense mutation } \\
\text { p.Gly761Ser (exon } \\
\text { 19) and mutation of } \\
\text { exon } 29 \\
\text { (4143_4144insA) }\end{array}$ & NA \\
\hline
\end{tabular}

Abbreviations: NA, not available. FFP, fresh frozen

Table 1: Review of previously reported late onset inherited TTP with stroke. 